\title{
BRINGING BACK THE BEAVER TO SASKATCHEWAN
}

With acknowledgnents to Mr. E. I. Paynter, Game Commissioner, Saskatchewan, and to Outdoor Camada

In the years following the first world war the Saskatchewan Government attempted to conserve its beaver population by ordinary "close" and "open" seasons, in the hope that the beavers would increase during the close seasons and trapping become possible once more. This policy caused rapid reduction of the heaver population, until soon there were vast areas, previously abounding with beavers, where the only signs of past plenty were wrecked dams and abandoned lodges. The policy was also detrimental to the way of life of the thousands of trappers. These men adopted "trap and get out" methods, perhaps making, and spending, several thousand dollars during an open season, but being left destitute and dependent on the State during the close seasons which followed.

In 1946, following a Government inquiry, all Crown lands north of $53^{\circ}$ latitude were made into a conservation block while, south of this, trapping was put on a quota so that enough beavers should be left for propagation. In the conservation block community trapping grounds were established adjacent to settlements. Here the resident trappers were given exclusive trapping rights. New settlers moving in had to establish a home and live there for a year before applying for trapping rights. No trapping at all was allowed until there were five occupied beaver lodges to each human family or individual, and even then only one beaver per lodge could be taken.

Beaver (and muskrat) skins taken in the conservation area were marketed under Government control, 10 per cent being deducted for rovalty and development.

The cost of the conservation scheme, $\$ 50,000$ a year for ten years, in which the muskrat was included, was borne 60 per cent by the Dominion and 40 per cent by the Saskatchewan Government, the Dominion's share being based on the 60 per cent Indian population in the conservation area. Councils, which worked in co-operation with natural resources field officers, were elected by the trappers in each district; Indians, Whites, and Ietis, $^{\mathbf{1}}$ were given equal rights and fair representation.

Now, in 1952, it is possible to see the result of this con-

${ }^{1}$ Metis : Offspring of a White and an American Indian.--Ed. 
servation scheme which has included the trapping and moving to conservation areas of 2,400 beavers. It has proved remarkably successful; no more movement of breeding stock is necessary and there is every indication that the beaver population will increase sharply in the years to come. The engineering ingenuity of the beaver is once again taking its part in the building and safeguarding of the forests of the province. Through the construction of dams the beaver establishes and maintains water levels, which in turn create pools essential to the other wild life. Furthermore, the broadened streams and dammed waters have proved invaluable in the control of fire, that great foe which jeopardizes both the wild life itself and also the livelihood of the trappers.

\section{WILD LIFE PROTECTION IN JAMAICA}

By F. W. Мarch, Conservator of Forests

In Jamaica the responsibility of administering the Wild Iife Protection Law rests with the Forest Department. The Department is assisted and directed by the Wild Life Protection Committee, a body nominated by His Excellency the Governor and consisting of legislators, scientists, sportsmen and Government officials. The policy of this Committee and the Forest Department is to ensure the protection of all forms of wild life consistent with the interests of legitimate sportsmen and with the control of pests.

Jamaica can rightly claim that its wild life includes unique examples of birds and animals. During comparatively recent years several species of birds and the once common iguana have become extinct; in every case the mongoose is largely to blame. The mongoose has now adjusted itself into the balance of nature but only at the expense of the elimination of practically all ground nesting birds. The avoidance of another such debacle, whether by human or natural agency, is one of the most important duties of the Wild Life Protection Committee.

The aspect of wild life conservation most in the public eye is the vexed question of game-hirds, what to shoot, when to shoot, and where to shoot.

Most species of pigeons and doves are classed as "game" and may be shot during the "open season ". Important exceptions are the Ruddy Quail Dove or Partridge, the Mountain Witch, and the Blue Pigeon: Imfortunately specimens of these 